\title{
KETIDAKHARMONISAN KOMUNIKASI DALAM KELUARGA PADA PEMBENTUKAN PRIBADI ANAK (PENDEKATAN HUMANISTIK)
}

\author{
Dyah Ayu Nidyansari \\ The London School of Public Relations \\ Email: nindya.sarii@yahoo.com
}

Diterima : 30 Juli 2018

Disetujui : 14 Agustus 2018

Diterbitkan : 31 Agustus 2018

\begin{abstract}
Abstrak
Penelitian ini bertujuan untuk mengetahui komunikasi dalam keluarga, pembentukan pribadi anak pada keluarga yang tidak harmonis, dan ketidakharmonisan komunikasi dalam keluarga pada pembentukan pribadi menyimpang anak. Metode yang digunakan pada penelitian ini adalah metode kualitatif dengan teknik pengumpulan data dengan wawancara mendalam pada tiga narasumber dan teknik analisa data dalam penelitian ini menggunakan model Huberman. Analisis data dilakukan secara kualitatif dan dikaji menggunakan teori komunikasi interpersonal dari Alvonco, J. Dari hasil penelitian dapat disimpulkan bahwa komunikasi interpersonal antar anak dan orangtua sangat dibutuhkan dalam keluarga, komunikasi yang kurang baik dalam keluarga dapat menimbulkan perpecahan antar anggota keluarga dan membuat anggota menutup untuk berkomunikasi satu sama lain sehingga kebutuhan seorang anak pada keluarga tidak harmonis, tidak terpenuhi sehingga anak sangat mudah terjerumus ke hal-hal negatif dan memiliki kepribadian menyimpang dalam bermasyarakat.
\end{abstract}

Kata Kunci: Anak, Harmonisasi, Humanistik, Komunikasi, Keluarga

\begin{abstract}
The relationship of a family is highly influenced by the role of the husband and wife, as a parent their views and their way of educating their kids will lead to the well-being of the family. This research aims to determine the importance of communicating is in a family and how it could mold the child to a non-harmonious family and disharmony communication in the family on the developing o children personality deviant. The method used in this research is a qualitative method of data collection techniques with in-depth interviews on three sources and data analysis techniques in this research used the Huberman. Data analysis was conducted qualitatively and studied using interpersonal communication theory from Alvonco, J. The result of this research is, that interpersonal communication between children and parents is needed in the family, poor communication within the family can cause divisions among family members and make members close to communicate with each other so that the needs of a child in the family is not harmonious unfulfilled so children are very easy to fall into the negatives and have a deviant person in the community.
\end{abstract}

Keywords: Children, Harmonization, Humanistic, Communication, Family

\section{PENDAHULUAN}

Menurut Duvall dan Logan, (1986) mengatakan bahwa keluarga adalah sekumpulan orang dengan ikatan perkawinan, kelahiran, dan adopsi yang bertujuan untuk menciptakan, mempertahankan budaya, dan meningkatkan perkembangan fisik, mental, emosional, serta sosial dari tiap anggota keluarga (Lestari, 2012).

Hubungan antar pribadi dalam keluarga sangat dipengaruhi oleh peranan suami istri, sebagai ayah-ibu dalam pandangan dan arah pendidikan yang akan mewujudkan suasana keluarga. Masing-masing pribadi diharapkan tahu perannanya dalam keluarga dan 
memerankannya dengan baik agar keluarga menjadi wadah yang tepat untuk perkembangan anggota keluarga secara wajar (Gunarsa dan Gunarsa, 2004, p.31).

Keluarga harmonis dan bahagia dalam sebuah keluarga merupakan salah satu hal penting yang tidak bisa disepelekan begitu saja. Keharmonisan dalam keluarga dapat menciptakan kebahagiaan yang tak terkira bagi setiap individu. Pasalnya, keluarga adalah lingkup kehidupan yang paling dekat dan sangat berharga. Untuk itu, memahami makna dan pengertian keluarga yang harmonis perlu dilakukan demi mewujudkan keluarga yang bahagia. Keluarga harmonis adalah keluarga yang rukun berbahagia, tertib, disiplin, saling menghargai, penuh pemaaf, tolong-menolong dalam kebajikan, memiliki etos kerja yang baik, bertetangga dan saling menghormati, taat mengerjakan ibadah, berbakti pada yang lebih tua, mencintai ilmu pengetahuan dan mamanfaatkan waktu luang dengan hal yang positif dan mampu memenuhi dasar keluarga (Basri, 1996).

Sebaliknya, ketidakharmonisan dalam keluarga biasanya berujung pada perceraian. Dalam sebuah perceraian sering dijumpai banyak faktor-faktor atau penyebab terjadinya perceraian, menurut Devie Rachmawati yang merupakan pengamat sosial budaya Universitas Indonesia, untuk faktor ekonomi hampir setiap pasangan pernah mengalami masa krisis ekonomi dalam keluarga. Pekerjaan yang tak tetap penghasilan yang minim membuat kebutuhan keluarga tak bisa dipenuhi, akibatnya keharmonisan dalam pernikahan juga terguncang, sedangkan bagi pasangan nikah dini, dosen Komunikasi Budaya Vokasi UI ini menilai, psikologis menjadi faktor yang signifikan sebagai penyebab perceraian. Umur yang belum matang bagi kedua pasangan menyebabkan kondisi emosi tidak stabil dan berakhir dengan pertengkaran antara suami dan istri. Kemudian, Devie menjelaskan, kurangnya tempat untuk berkeluh kesah dan orang yang sanggup memberikan nasihat terkait masalah pernikahan, juga membuat pasangan lebih memilih bercerai sebagai solusi utama dalam pernikahan, karena mereka berpikir perceraian tidak melunturkan arti pernikahan. Bahkan mereka tidak berpikir bahwa perceraian akan berdampak pada perkembangan anak. Seharusnya sebagai orangtua harus memikirkan buah cintanya (Arjawinangun, 2014).

Suatu permasalahan pasti menimbulkan dampak. Begitu juga dampak dari perceraian, ketidakharmonisan dalam suatu keluarga ketika satu keluarga mengalami perceraian bukan hanya suami atau istri yang terlibat di dalam hal tersebut karna bentuk dari keluarga inti terdiri dari ayah, ibu, dan anak, maka hal tersebut juga berdampak kepada anak. Hasil riset menunjukkan bahwa anak di keluarga yang hanya memiliki orangtua tunggal, rata-rata cenderung kurang mampu mengerjakan sesuatu dengan baik dibandingkan anak yang berasal dari keluarga yang orangtuanya utuh (Republika, 2008). Anak yang dibesarkan di keluarga hasil perceraian cenderung sulit menyesuaikan diri dengan lingkungan, kesulitan datang secara alamiah dari diri anak tersebut. Hurlock mengungkapkan bahwa "Dampak remaja korban perceraian orangtua, antara lain mudah emosi, kurang konsentrasi belajar, tidak peduli terhadap lingkungan dan sesamanya, tidak tahu sopan santun, tidak tahu etika bermasyarakat, dan senang mencari perhatian orang". Hal tersebut bisa dikategorikan bahwa dampak dari perceraian bisa membuat anak memiliki penyimpangan pribadi (dalam Widyarini, 2009, p.42-46).

Menurut Robert MZ. Lawang penyimpangan dapat dibedakan menjadi dua macam, yaitu penyimpangan premier dan penyimpangan sekunder. Penyimpangan premier adalah suatu bentuk perilaku menyimpang yang bersifat sementara dan tidak dilakukan terus menerus sehingga masih dapat ditolerir masyarakat, seperti melanggar rambu lalu lintas, buang sampah sembarangan, dan sebagainya. Sedangkan, penyimpangan sekunder ialah perilaku menyimpang yang tidak dapat ditoleransi oleh masyarakat dan umumnya dilakukan berulang-ulang contohnya seperti merampok, menjambret, memakai narkoba, dan menjadi pelacur. Ada pula penyimpangan yang dinamakan individual (individual deviation) 
penyimpangan individual merupakan suatu perilaku seseorang dengan melakukan pelanggaran terhadap suatu norma pada kebudayaan yang telah mapan, akibatnya sikap perilaku yang jahat atau terjadinya gangguan jiwa pada seseorang. Macam - macam bentuk penyimpangan individual adalah seperti penyalahgunaan narkoba, pelacuran, penyimpangan seksual (homo, lesbian, biseksual, pedofil, sodomi, zina, seks bebas, transeksual) (Septiana, Nugroho, dan Purwandari, 2008, p.15).

Merdeka, (2013) mengungkapkan bahwa jumlah PSK saat ini, 30 persen di antaranya masih di bawah usia 19 tahun. "Di bawah umur antara usia 14-19 tahun". Selain itu, angka kematian akibat penyalahgunaan narkoba diperkirakan mencapai 104.000 orang dimana masih berumur 15 tahun (PortalIndonesianews, 2015). Dengan demikian, berbagai uraian di atas menunjukan bahwa hal- hal tersebut sangat menarik untuk diteliti atau dianalisa lebih mendalam terkait dengan bagaimana ketidakharmonisan komunikasi dalam keluarga mempengaruhi pada pembentukan pribadi menyimpang anak.

\section{METODOLOGI PENELITIAN}

Metode penelitian yang digunakan dalam penelitian ini adalah studi kasus dengan pendekatan kualitatif. Menurut Catherine Marshal, (1995) penelitian kualitatif didefinisikan sebagai suatu proses yang mencoba untuk mendapatkan pemahaman yang lebih baik mengenai kompleksitas yang ada di dalam interaksi manusia (dalam Sarwono, 2006, p.193). Sementara itu, studi kasus merupakan suatu metode penelitian ilmu-ilmu sosial, selain itu studi kasus berfokus pada penelitian fenomena dalam konteks kehidupan nyata (Yin, 2004, p.1). Dalam penelitian ini menggunakan tipe studi kasus desktiptif karena dianggap paling sesuai untuk menjawab rumusan masalah penelitian. William $\mathrm{F}$. Whyte mengungkapkan bahwa studi kasus deskriptif merupakan studi kasus tunggal yang mencakup sebuah lingkungan sosial (Cornerville) untuk melacak urutan peristiwa hubungan antar pribadi, serta berkemampuan mengeneralisasi terhadap isu-isu seperti unjuk kerja perorangan, struktur kelompok, dan struktur lingkungan sosial. Keluarga merupakan struktur kelompok yang banyak memiliki berbagai isu di dalamnya (dalam Yin, 2004, p.3-5).

Penelitian ini menggunakan data primer dimana data didapatkan dari tiga narasumber. Data Primer adalah data berupa hasil wawancara dan diperoleh melalui wawancara dengan narasumber yang dijadikan sampel penelitian. Data direkam atau dicatat oleh peneliti (Sarwono, 2006, p.209). Selanjutnya, narasumber ialah orang yang memberikan suatu keterangan atau informasi terkait dengan penelitian yang didasarkan oleh faktor subjektif yang dimiliki, serta berdasarkan latar belakang pengalaman, dan juga peran (Sutarni dan Sukardi, 2008, p.39). Tiga narasumber tersebut tentunya memiliki latar belakang yang berbeda, selengkapnya berikut adalah penjelasan terkait narasumber (sumber data) dalam penelitian ini. Dalam penelitian ini dilakukan wawancara langsung dengan narasumber dari tiga anak dengan tiga orangtua yang berasal dari keluarga yang berbeda, antara lain sebagai berikut:

1. Citra (bukan nama sebenarnya) dari umur tiga tahun, Citra sudah berpisah dengan ayahnya dikarenakan orangtua mereka mengalami perceraian akhirnya menyukai pria yang jauh lebih dewasa darinya.

2. Caca (bukan nama sebenarnya), Caca adalah anak pertama dari dua bersaudara, dari usia satu tahun, ibunya kabur meninggalkan Caca dan ayahnya, dan sekarang Caca menjadi pencandu dan pelaku sex bebas.

3. Farhan (bukan nama sebenarnya), Farhan ingat sejak berusia 12 tahun, Ia sering sekali melihat kekerasan di dalam rumah dimana ibunya sering dipukuli oleh ayahnya. Bukan hanya melihat, bahkan Farhan juga pernah mendapatkan kekerasan 
fisik dari ayahnya. Sekarang Farhan memiliki disorientasi seksual, Ia merupakan pelaku homoseksual atau penyuka sesama jenis.

Teknik wawancara yang digunakan dalam penelitian ini ialah in-depth Interview, dimana dalam pendeketan kualitatif terdapat tiga kategori wawancara, yakni wawancara dengan melakukan pembicaraan informal, wawancara umum yang semi-terstruktur, dan wawancara terbuka yang bersifat standart.

Keunggulan utama wawancara adalah memungkinkan peneliti mendapatkan jumlah data yang banyak. Pada dasarnya, Penelitian ini berfokus pada bagaimana pentingnya peran komunikasi interpersonal dalam suatu kelompok. Komunikasi yang terjadi dalam kelompok keluarga yang tidak harmonis pada pembentukan penyimpangan kepribadian anak di masa depan. Serta, sistem dasar pokok pembentukan kepribadian yang membahas pentingnya peran komunikasi dalam pembentukan kepribadian anak (Hall dan Lindzey, 2005, p.80). Secara komprehensif, berikut adalah gambaran fokus dalam penelitian ini:

Tabel 1. Fokus Penelitian

\begin{tabular}{|c|c|c|c|}
\hline $\begin{array}{c}\text { Fokus } \\
\text { Penelitian }\end{array}$ & Elemen & Evidensi & Metode \\
\hline $\begin{array}{l}\text { Humanistic } \\
\text { Model } \\
\text { (Alvonco, } \\
2014, \text { p.58) }\end{array}$ & $\begin{array}{l}\text { 1. Openness } \\
\text { 2. Supportiveness } \\
\text { 3. Positiveness } \\
\text { 4. Emphaty } \\
\text { 5. Equality }\end{array}$ & $\begin{array}{l}\text { 1. Membuat interaksi di dalam } \\
\text { keluarga bersifat terbuka, yaitu } \\
\text { pesan yang disampaikan secara } \\
\text { jelas dan dapat dipahami. } \\
\text { 2. Memberikan kesempatan bagi } \\
\text { anggota keluarga yang ingin } \\
\text { meyampaikan pendapatnya. } \\
\text { 3. Mendengarkan dan menghormati } \\
\text { jika anggota keluarga } \\
\text { membutuhkan tempat berbagi. } \\
\text { 4. Mendefinisikan apa yang sedang } \\
\text { dialami komunikator, memahami } \\
\text { serta memotivasi. } \\
\text { 5. Antara receiver dan sender harus } \\
\text { mempunyai nilai-nilai dimana } \\
\text { antara sender dan receiver } \\
\text { memiliki sesuatu yang berharga } \\
\text { untuk dibagikan atau } \\
\text { diinformasikan, maka disitulah } \\
\text { terjadi kesetaraan. }\end{array}$ & $\begin{array}{c}\text { Kualitatif dan } \\
\text { wawancara } \\
\text { mendalam } \\
\text { terhadap tiga } \\
\text { keluarga } \\
\text { narasumber }\end{array}$ \\
\hline
\end{tabular}

Sumber: Diolah oleh Peneliti, (2017)

Analisis data yang dilakukan dalam penelitian ini ialah proses mencari, menyusun, serta menyimpulkan hasil dari wawancara, catatan lapangan, dan informasi lainnya, sehingga dapat dipahami maksud dan kesimpulan dari penelitian. Pengumpulan data dilakukan dengan cara sebagai berikut:

1. Reduksi data, yaitu proses pemilihan, pemusatan perhatian pada penyederhanaan, pengabstrakan, dan transformasi data dari catatan-catatan yang tertulis di lapangan.

2. Penyajian data, yaitu dengan membatasi penyajian data yang didapat dari lapangan kemudian membuang yang tidak perlu disajikan dan menyusun informasi yang relevan dengan penelitian, sehingga data menjadi sempit yang mungkin dapat memberi kesimpulan dan pengambilan tindakan. 
3. Menarik kesimpulan atau verifikasi, mencari arti dari informasi-informasi yang didapat dari lapangan dan mencari permasalan yang relevan pada penelitian yang dilakukan (Huberman, 2007, p.15-19).

Selanjutnya, dalam konteks pengujian validitas data, peneliti menggunakan pendekatan yang disebut dengan 'memperluas harapan awal', yaitu dengan mengumpulkan serta mempelajari data-data sehingga memunculkan asumsi-asumsi awal terhadap penelitian, serta fokus pada teknik triangulasi, yaitu dengan mencari pemahaman yang didapat dari hasil penelitian dan menggabungkan data-data yang ada, serta meminta bantuan dilakukannya pengecekan oleh akademisi dengan menggunakan review dari mulai permasalahan, data, teknik analisis, dan hasil dari penelitian (Sarwono, 2006, p. 245-246).

Penelitian dilaksanakan pada bulan Desember 2016 sampai dengan Mei 2017, dengan menggunakan media komunikasi alat perekam melalui wawancara langsung dengan narasumber yang berada di Jakarta.

\section{HASIL DAN PEMBAHASAN}

Penelitian ini membahas komunikasi interpersonal antara orangtua dan anak di dalam keluarga yang tidak harmonis yang menjadikan anak mempunyai penyimpangan sikap. Ketidakharmonisan keluarga dapat memberikan hal yang negatif pada pembentukan kepribadian anak, sehingga sikap menyimpang pada anak dari keluarga yang tidak harmonis sangat memungkinkan terjadi (Widyarini, 2009, p.42-46).

Fenomena ketidakharmonisan keluarga sering terjadi di masyarakat dikarenakan beberapa faktor salah satunya adalah dampak dari ketidakefektifan komunikasi yang terjadi dalam keluarga. Komunikasi merupakan hal yang sangat penting dalam menjalin suatu hubungan baik termasuk hubungan keluarga, menjaga komunikasi yang baik serta intensif akan menghasilkan hubungan yang baik pula, sehingga tidak terjadi kesalahpahaman di antara kedua belah pihak dan tidak menjadi penyebab rasa cinta berkurang. Melakukan komunikasi terus menerus adalah hal yang sangat penting seperti mengabarkan jika terjadi sesuatu atau akan melakukan suatu hal yang belum direncanakan atau secara tiba-tiba agar di antara kedua pihak tetap berprasangka baik, sehingga menghindari adanya pikiran-pikiran negatif yang dapat memicu adanya pertengkaran bahkan sampai perceraian (Cintalia, 2016).

Temuan dalam penelitian ini mengacu pada lima elemen (openness, supportiveness, positiveness, emphaty, dan equality) yang terdapat pada Humanistic Model yang dikembangkan oleh Alvonco, (2014, p.58). Pertanyaan pertama bertujuan untuk melihat adanya keterbukaan (openness) yang terjadi di dalam komunikasi antar pribadi yang terdapat di dalam keluarga narasumber. Berikut hasil wawancara bersama Caca, Citra, dan Farhan terkait elemen openness:

"Belum, saya sudah mencoba untuk berkomunikasi dengan baik atau senormalnya namun ga sebaliknya meski di perbolehkan bersuarapun tidak didengar sama sekali, jadi komunikasi saya dan keluarga agak percuma sebenarnya". - Caca

"Belum, karna masing-masing memiliki kesibukan dan menganggap tidak penting dalam berpendapat yang paling berwenang mengajukan pendapat hanya orangtua, saya sebagai anak harus ikut keinginannya walaupun bertentangan dengan pendapat saya”. - Citra

"Belum, disebabkan banyak faktor contohnya rasa takut dan rasa cemas malu untuk berkomunikasi karna kita jarang komunikasi atau bicara, karena merasa 
kurang pantas aja untuk mencampuri urusan-urusan dalam keluarga”. Farhan

Menurut Devito, sifat keterbukaan menunjukan paling tidak dua aspek tentang komunikasi antarpribadi, aspek pertama adalah bahwa dibutuhkannya keterbukaan pada orang-orang yang melakukan interaksi. Aspek kedua, dari keterbukaan dapat menunjukan kemauan untuk memberikan tanggapan terhadap orang lain dengan jujur (dalam Fajar, 2009, p.84). Berdasarkan hasil wawancara di atas, ketiga narasumber menunjukkan bahwa komunikasi antara anak dan orangtua di dalam keluarga kurang baik dan tidak menjalankan dua aspek di atas karena disebabkan orangtua mereka yang kurang membuka komunikasi yang harusnya dapat diciptakan antara anak dan orangtua, namun berbeda dengan Caca dan Citra, Farhan menutup diri untuk berkomunikasi dengan orangtuanya karena disebabkan ketakutan-ketakutan tidak diterimanya pendapat yang ingin disampaikan dan mengarah pada pemikiran-pemikiran negatif, sehingga komunikasi tertutup dan kurang efektif tersebut terjadi berulang-ulang.

Pertanyaan berikutnya merupakan sikap orangtua (emphaty), jika anak sedang menghadapi suatu masalah yang sulit, serta nasihat-nasihat yang mereka berikan. Berikut hasil wawancaranya:

"Kalo nasihat pernah, tapi dulu pas SD tapi misalnya saya punya masalah mereka melihatnya dengan mata mereka sendiri, mereka juga cenderung bereaksi negatif, komentarin atau nge-judge”. - Caca

"Sikap kalo saya menceritakan tentang masalah ke orangtua tidak ada penyelesaian, mereka cendrung membiarkan anaknya menghadapi masalah sendiri, sehingga jika saya ada masalah saya tidak menceritakan lagi tentang masalah saya”. - Citra

"Sikap orangtua saya jika saya ada masalah biasanya kurang memperhatikan permasalahan yang saya alami, bisa dibilang kurang peka atau peduli walaupun saya menunjukan tingkah laku yang berbeda jika sedang menghadapi masalah". - Farhan

Devito menyatakan bahwa kemauan seseorang untuk menepatkan dirinya pada peranan atau posisi orang lain dapat membuat komunikasi yang dilakukan menjadi efektif dan kondusif (dalam Fajar, 2009, p.85). Dalam keluarga bentuk kepedulian di sini tidak selalu materi, tetapi juga berupa perhatian, penerimaan, penyediaan waktu, pikiran dan hati untuk sesama yang sedang membutuhkan hal-hal semacam itu (Gea et. al., 2004, p.269). Berdasarkan hasil wawancara di atas, seluruh narasumber merasa bahwa mereka kurang mendapatkan sikap serta tanggapan yang baik dari orangtua jika mereka sedang menghadapi masalah. Sehingga dari ketiga narasumber memutuskan untuk tidak menceritakan masalahmasalah yang sedang mereka hadapi dan mencari jalan keluar sesuai pola pikir dari masingmasing narasumber tanpa adanya peran orangtua di dalamnya, dalam hal ini sering kali mereka kerap mencari solusi kepada teman-teman mereka untuk menyelesaikan masalahnya karena waktu yang kurang dari orangtua, maka sebenarnya kepedulian waktu yang dibutuhkan untuk mendengar dan juga diharapkan orangtua dapat merasakan perasaan yang sedang dialami oleh anak, sehingga terciptanya rasa nyaman dalam berkomunikasi.

Selanjutnya, peneliti ingin mengetahui kemungkinan adanya elemen dukungan (supportiveness) dari orangtua dalam keputusan besar dalam hidup yang diperlukan seorang 
anak agar terciptanya komunikasi yang baik di dalam keluarga. Berikut adalah hasil wawancara terkait elemen ini, antara lain sebagai berikut:

"Buat hal-hal yang penting banget di hidup saya tuh mereka kurang contohnya buat kuliah mereka harusnya mendukung dimana anak pintarnya di waktu SMA ini malah suruh saya masuk ke jurusan yang saya kurang suka dan sekarang kuliahnya agak percuma karna ga sesuai “. - Caca

"Pernah, yaitu waktu kuliah beliau menyarankan memilih salah satu universitas, tapi dalam hal pekerjaan dan perilaku dalam kehidupan sosial tidak pernah”. - Citra

"Salah satu dari orangtua saya, yaitu ibu saya dia selalu menasihati saya contohnya saya mendapat nilai jelek terkadang saya ditanyakan bagaimana di sekolah tadi dia selalu menanyakan hal-hal kecil dia lebih perhatian ke saya, kalau papah saya kurang ya kurang banget karna dia agak sibuk dalam pekerjaannya dan saya juga agak takut untuk bicara sama papah saya”. Farhan

Jack R. Gibb menyebutkan bahwa ada tiga hal yang dapat menimbulkan perilaku supportif dalam komunikasi antarpribadi yakni deskriptif, spontanitas, dan provisionalsime (dalam Fajar, 2009, p.84). Berdasarkan hasil wawancara di atas menunjukan bahwa salah satu narasumber, yaitu Caca kurang mendapat dukungan (supportiveness) dari orangtua yang menyangkut hal penting dalam kehidupannya, oleh sebab itu, saat ini Caca berhenti kuliah karena merasa jurusan yang diambil dalam kuliah tidak sesuai dengan kemampuan yang di miliki dan dapat dilihat jika dikaitkan dengan teori di atas, maka tidak terdapat perilaku komunikasi supportif (deskriptif, spontanitas, dan provisionalisme) di antara Caca dan orangtuanya. Sedangkan, Citra dan Farhan mendapatkan dukungan dari salah satu orangtuanya terkait dengan masa depannya di dalam bidang pendidikan. Namun, hal yang membedakan antara Citra dan Farhan, yaitu Citra merasa orangtuanya tidak mendukung dalam hal pekerjaannya, serta dukungan dalam berkehidupan sosial. Sementara itu, Farhan tidak mendapat dukungan sama sekali dari ayahnya.

Keempat, dilakukan wawancara mengenai perasaan positif yang mampu menciptakan komunikasi yang kondusif dan menjadikan komunikasi tersebut efektif (positiveness). Berikut hasil wawancara dengan ketiga narasumber dalam penelitian ini:

"Kalo saya si coba diskusi dengan mereka, saya niat berdiskusi dengan kepala dingin dan gak emosi, namun di pihak yang lain (orangtua) nampaknya mereka ga mampu menyelesaikan masalah, malah mereka gamau cari solusi dan seakan-akan ga pernah ada masalah". - Caca

"Lari dari rumah si biasanya kalo lagi emosi setelah udah ga emosi baru balik, biasanya nginep di rumah temen sampe emosi reda, karena dari orangtua kalo dihadapi pada saat bersamaan mereka juga merasa yang paling benar". - Citra

"Saya lebih baik diam dan menyendiri dan berusaha menenangkan diri saya sendiri, saya lebih suka keluar rumah gitu, bertemu dengan teman sharing dengan teman lebih suka keluar rumah karna di dalam rumah saya merasa 
tidak aman dan tidak nyaman ga enak aja saya lebih suka di rumah teman saya”. - Farhan

Dalam teori Devito, komunikasi antar pribadi akan berkembang bilamana pandangan positif terhadap orang lain dalam berbagai situasi komunikasi (dalam, Fajar, 2009, p.85). Dari ketiga narasumber yang telah diwawancarai, peneliti mendapatkan perbedaan pernyataan dari narasumber pertama dengan narasumber kedua, dan ketiga. Dalam pernyataan narasumber pertama, yaitu Caca, Ia mencoba untuk menciptakan aspek positiveness, namun orangtua yang menghambat untuk terjadinya komunikasi yang efektif antara kedua pihak. Sedangkan, pada narasumber kedua dan ketiga, yaitu Citra dan Farhan menunjukkan untuk menutup komunikasi dan menghindar jika terjadinya konflik antara narasumber dan orangtua, sehingga tidak terciptanya rasa positiveness yang menyebabkan komunikasi tidak efektif dan masalah yang terjadi tidak dapat diselesaikan dengan baik, dikarenakan tidak adanya komunikasi positif.

Dalam komunikasi interpersonal dibutuhkan juga kesetaraan dan kesamaan (equality) dalam berkomunikasi, yaitu pengakuan bahwa kedua belah pihak menghargai, berguna, dan mempunyai sesuatu yang penting untuk disumbangkan. Dalam hal ini pertanyaan yang diajukan oleh peneliti adalah pandangan narasumber terhadap keluarga narasumber masingmasing. Berikut adalah hasil wawancara selengkapnya:

"Keluarga saya itu penyebar virus negatif contohnya saya berbicara seperti ini karena setiap harinya selalu di perlakukan sinis oleh ayah kadang dia ngamuk-ngamuk manggil saya untuk mengerjakan sesuatu yang sebenernya dia bisa lakukan sendiri”. - Caca

"Keluarga saya adalah keluarga yang tidak fungsional disini maksudnya peran ayah terhadap keluraga yaitu dengan memberikan sandang, pangan, dan pendidikan yang tidak terlaksanakan”. - Citra

"Pandangan saya terhadap keluarga saya adalah sangat tidak baik di sebabkan karna adanya trauma yang sangat mendalam di diri saya disebabkan karna adanya kekerasan yang di lakukan oleh ayah saya, kekerasan yang di lakukan baik verbal maupun non verbal". - Farhan

Di dalam komunikasi keluarga diperlukannya kesetaraan agar masing-masing anggota keluarga mempunyai rasa saling membutuhkan yang meciptakan rasa saling melengkapi yang menjadikan keluarga utuh, rukun, dan bahagia (Devito, 2009, p.263-264). Dalam temuan di atas dapat lihat bahwa orangtua lebih mendominasi di dalam komunikasi keluarga, sehingga seorang anak tidak dapat menyampaikan pendapat dan keluh kesah yang ingin disampaikan kepada orangtua, serta penyalahgunaan peran dan kewajiban masingmasing anggota keluarga, sehingga tidak terciptanya rasa saling melengkapi yang menjadikan keluarga utuh, rukun, dan bahagia.

Secara keseluruhan dari hasil wawancara di atas menunjukan bahwa di dalam ketiga keluarga dari ketiga narasumber, dapat dijelaskan bahwa unsur-unsur penting yang seharusnya diperlukan dalam komunikasi interpersonal, yaitu keterbukaan (openness), memahami kondisi dan perasaan orang lain (emphaty), saling mendukung (supportiveness), positif (positiveness), dan kesetaraan (equality) yang dapat membuat kedua belah pihak akan berada dalam situasi yang nyaman dan mendorong terciptanya komunikasi yang efektif dan kondusif kurang tercipta (Alvonco, 2014, p.58). 
Setelah peneliti melakukan analisa, maka ditemukan bahwa sebagai makhluk sosial manusia tidak dapat lepas dari orang lain yang akan selalu dan dibutuhkan dalam hubungan sosial. Dalam hubungan inilah proses komunikasi interpersonal dilakukan karna prinsip komunikasi interpersonal adalah melibatkan komunikasi antara dua orang atau lebih yang dilakukan secara tatap muka (face to face communication) (Alvonco, 2014, p.57). Mengacu pada teori di atas, komunikasi interpersonal yang dibahas dalam penelitian ini adalah komunikasi interpesonal yang terjadi di dalam keluarga dimana anggota keluarga yang berjumlah lebih dari dua orang, sehingga adanya komunikasi interpersonal di dalam keluarga.

Penelitian ini menggunakan teori interpersonal komunikasi yang berfokus pada pendekatan humanistik yang dimana ada lima evidensi yang harus ada di dalam komunikasi interpersonal, agar komunikasi yang dilakukan menjadi efektif, yaitu keterbukaan (openness), empati (emphaty), sikap mendukung (supportiveness), sikap positif (positiveness), kesetaraan (equality) (Alvonco, 2014, p.58).

Dari hasil temuan penelitian ini ditemukan bahwa dalam ketiga keluarga narasumber tidak menerapkan beberapa evidensi yang membuat komunikasi menjadi tidak harmonis, sehingga terjadi berbagai permasalahan yang timbul, karena salah satu anggota keluarga, yaitu orangtua tidak membahas masalah-masalah yang ada dengan cara berkomunikasi melainkan dengan menutup diri untuk melakukan komunikasi tersebut. Akibatnya sang anak mencurahkan isi hatinya kepada orang lain yang mereka percaya seperti teman dan masukanmasukan yang belum tentu benar, sehingga memudahkan mereka untuk terjerumus kepada hal-hal yang negatif dan dapat berpengaruh pada perilaku anak di kehidupan sosial.

Menurut Devito, (2009, p.260) mengubah kebiasaan dalam bersikap sangatlah sulit, padahal sekeras mungkin seseorang ingin merubah kebiasaannya. Maka, perlu diketahui bahwa kebiasaan-kebiasaan atau perilaku yang ada di dalam diri saat ini dapat dipengaruhi oleh anggota keluarga.

Mengacu pada teori di atas, maka dapat disimpulkan bahwa setiap perilaku yang dilakukan oleh sang anak, baik itu perilaku yang baik ataupun yang buruk, dipengaruhi oleh adanya faktor-faktor kebiasaan yang dilakukan di dalam keluarga seperti pada penelitian ini salah satu narasumber melakukan hal-hal yang melanggar norma-norma yang berlaku dalam bermasyarakat seperti mabuk-mabukan, melakukan sex bebas, serta mencoba narkoba karena dipicu dari sikap orangtuanya yang melakukan hal-hal tersebut, maka sang anak mencontoh dan melakukan hal yang sama.

Menurut Freud ada tiga sistem pokok tersusun yang dapat membentuk kepribadian yaitu id, ego, dan super ego. Meskipun masing-masing mempunyai fungsi, sifat, komponen, prinsip kerjanya sendiri, tetapi ketiga hal ini saling berkaitan, mereka saling berinteraksi begitu erat sehingga sulit untuk memisahkan pengaruh terhadap tingkah laku pada manusia (Hall dan Lindzey, 2005, p.63-p.67).

Peneliti menemukan bahwa dalam kasus ini karena kurang harmonisnya komunikasi di dalam ketiga keluarga narasumber, maka mengakibatkan ketiga narasumber lebih bermain dengan egonya, karena super ego didapat dari nasihat-nasihat orangtua dan nasihat bisa didapat dan diterima oleh sang anak, jika komunikasi interpersonal dalam keluarga berjalan lancar, tetapi nyatanya tidak didapat dan diterima karena dalam ketiga keluarga narasumber tidak melakukan komunikasi interpersonal dengan baik, sehingga ego yang bermain dalam kehidupan mereka yang mengakibatkan adanya penyimpangan perilaku seperti sex bebas, narkoba, mabuk-mabukan, homoseksual, terjerumus dalam pelacuran, dan hal-hal negatif lainnya.

Hasil penelitian ini konsisten mendukung studi terdahulu yang dilakukan oleh Fauzi, (2014) berjudul "Hubungan Keharmonisan Keluarga dengan Perkembangan Moral Siswa 
Kelas IV dan V di MI Darul Falah, Ngerangkok Klampisan Kandangan Kediri” yang berhasil membuktikan bahwa keharmonisan keluarga berpengaruh positif dan signifikan terhadap perkembangan moral siswa atau dengan kata lain apabila harmonisasi dalam keluarga meningkat, maka hal tersebut mampu meningkatkan moral siswa, begitu pula sebaliknya. Ia mengungkapkan bahwa lembaga pendidikan dalam pengertian masyarakat adalah sekolah, pondok pesantren, lembaga kursus, dan lain -lain, namun pengertian tersebut adalah kurang tepat karena keluargalah yang merupakan lembaga pendidikan pertama bagi setiap anak, dimana pengarahan terhadap norma-norma masyarakat dan nilai - nilai keagamaan pertama kali dikenalkan oleh kedua orang tua dan disempurnakan oleh lembaga pendidikan dengan mensistematisasikan sistem pendidikan dengan mengacu pada standarisasi pendidikan nasional (Fauzi, 2014).

Selain itu, temuan dalam penelitian juga sejalan dengan studi yang dilakukan oleh Rafiq, (2014) berjudul "Hubungan Pola Komunikasi Interpersonal dalam Keluarga dan Interaksi Sosial Terhadap Kenakalan Siswa SMA Swasta di Kota Padangsidimpuan". Penelitian in menunjukkan bahwa terdapat hubungan yang sangat signifikan (sangat kuat) antara pola komunikasi interpersonal dalam keluarga dengan kenakalan siswa yang artinya bahwa semakin baik pola komunikasi dalam keluarga maka semakin kecil tingkat kenakalan siswa. Begitu pun sebaliknya. Selanjutnya, penelitian tersebut juga berhasil membuktikan bahwa terdapat hubungan yang sangat signifikan (sangat kuat) antara interaksi sosial dan kenakalan siswa yang artinya bahwa semakin baik interaksi sosial siswa, maka semakin kecil tingkat kenalan siswa.

Begitu juga sebaliknya. Rafiq, (2014) mengungkapkan bahwa dalam lingkungan keluarga, anak mengembangkan pemikiran tersendiri yang merupakan pengukuhan dasar emosional dan optimisme sosial melalui frekuensi dan kualitas komunikasi dengan orang tua dan saudara-saudaranya. Proses komunikasi ini turut mempengaruhi perkembangan sosial dan gaya hidupnya di masa mendatang. Dalam lingkungan sekolah, anak belajar membina hubungan dengan teman-teman sekolahnya yang datang dari berbagai keluarga dengan status dan warna sosial yang berbeda. Dalam lingkungan masyarakat, anak dihadapkan dengan berbagai situasi dan masalah kemasyarakatan.

Pola komunikasi dalam keluarga memiliki pengaruh kuat terhadap perkembangan jiwa dan hubungan sosial remaja karena sebagian besar kehidupannya ada di dalam keluarga. Situasi interaksi antara anggota keluarga, perlakuan anggota keluarga terhadap remajanya, memiliki pengaruh kuat terhadap kondisi psikis remaja. Akhirnya keharmonisan hubungan yang diwujudkan dengan pola komunikasi yang baik antara keluarga, serta interaksi di lingkungan sosialnya juga berpengaruh pada kenakalan remaja. Oleh karena itu, kenakalan remaja dapat terjadi apabila pola komunikasi keluarga dan interaksi sosial tidak berlangsung dengan baik (Rafiq, 2014).

Dapat dilihat juga dari pembahasan di atas bahwa komunikasi dalam keluarga sangat penting dilakukan dan dijalankan dengan harmonis karena tidak harmonisnya komunikasi dalam keluarga berdampak pada kehidupan anak di masa depan, karena kurangnya komunikasi dapat berpengaruh pada faktor-faktor lain salah satunya faktor psikologi.

\section{PENUTUP}

Berdasarkan hasil penelitian ini mengenai "Ketidakharmonisan Komunikasi Dalam Keluarga Pada Pembentukan Pribadi Anak" yang diperoleh dari hasil wawancara secara mendalam dengan tiga narasumber, maka dapat ditarik beberapa kesimpulan. Pertama, komunikasi dalam keluarga sangat dibutuhkan terutama oleh anak karena di dalam komunikasi dapat menciptakan rasa kasih sayang antar anggota keluarga serta pemahamanpemahaman yang dapat menjadikan keluarga mengerti akan peranan masing-masing, serta 
membuat keluarga semakin harmonis, namun jika komunikasi dalam keluarga tidak berjalan baik maka sebaliknya, tidak ada rasa kasih sayang antar anggota keluarga dan tidak ada kejelasan peran pada masing-masing anggota, sehingga fungsi dan peranan keluarga tidak jalan sebagimana mestinya. Kedua, orangtua sangat berperan penting pada pembentukan pribadi anak, karna pribadi terbentuk pada saat anak masih berusia dini, sehingga pada saat itulah peran orangtua dibutuhkan seperti memberikan rasa kasih sayang, perhatian, kepedulian, serta nasihat-nasihat positif yang dapat menjadikan anak menjadi pribadi yang baik. Ketiga, komunikasi yang kurang baik dalam keluarga dapat mengakibatkan terjadinya perpecahan antar anggota keluarga yang menyebabkan komunikasi keluarga tidak berjalan harmonis dan membuat anggota menutup untuk berkomunikasi satu sama lain, sehingga timbul disharmonisasi dan tidak terpenuhinya dukungan moral yang dibutuhkan. Tidak adanya nasihat-nasihat yang seharusnya diberikan orangtua, maka seorang anak akan mencari nasihat-nasihat dari orang lain yang belum tentu kebenarannya, dampaknya anak menjadi sangat mudah terjerumus ke berbagai hal negatif dan memiliki pribadi yang menyimpang dalam bermasyarakat.

Berdasarkan hasil penelitian mengenai ketidakharmonisan komunikasi dalam keluarga pada pembentukan pribadi anak (pendekatan humanistik), maka diharapkan penelitian selanjutnya dalam melakukan pengembangan penelitian dengan menggunakan studi kuantitatif. Selain itu, disarankan orangtua dapat menjaga keharmonisan komunikasi dalam keluarganya, serta menjaga komunikasi antar orangtua dan anak yang diisi dengan keterbukaan, sikap mendukung, empati, sikap positif, serta kesetaraan dalam berkomunikasi yang menjadikan terciptanya komunikasi yang baik dan terciptanya keluarga harmonis, serta pemberian nasihat-nasihat agar seorang anak merasa orangtua berperan, serta mendukung anak dalam hal-hal yang bersifat positif guna menciptakan anak dengan pribadi yang baik.

\section{REFERENSI}

Alvonco, J. (2014). Practical Communication Skill. Jakarta: Elex Media Komputindo.

Arjawinangun, K. B. (2014, Agustus). Empat Faktor Penyebab Perceraian. Diperoleh dari website: http://metro.sindonews.com/read/ 890610/31/empat-faktor-penyebabperceraian-1407868216.

Basri, H. (1996). Pengertian Keharmonisan Rumah Tangga. Diperoleh dari website: http://tulisanterkini.com/artikel/artikel-ilmiah/8998-pengertian-keharmonisan-rumahtangga.html

Cintalia. (2016). 28 Penyebab Perceraian Suami Istri yang Paling Sering Terjadi. Diakses dari: https://cintalia.com/cinta/perceraian/penyebab-perceraian-suami-istri.

Devito, J. A. (2009). Interpersonal Communication. Boston Pearson Education, Inc.

Duvall \& Logan. (1986). Marriage \& Family Development. New York: Harper \& Row Publisher.

Fajar, M. (2009) Ilmu Komunikasi Teori \& Praktik. Yogyakarta: Graha Ilmu.

Fauzi, R. (2014). Hubungan Keharmonisan Keluarga dengan Perkembangan Moral Siswa Kelas IV dan V di MI Darul Falah, Ngerangkok Klampisan Kandangan Kediri. STITNU Al Hikmah Mojokerto. Vol. II, No. 2, September 2014.

Gea, A. Wulandari, Y \& Babari, Y. (2004). Relasi Dengan Sesama, Jakarta: PT Gramedia.

Gunarasa, S. \& Gunarsa, Y. S. D. (2004). Psikologi Praktisi: Anak, Remaja, dan Keluarga. Jakarta: Gunung Mulia.

Hall, C. S. \& Lindzey, G. (2005). Teori-Teori Psikodinamik: Ikologi Kepribadian, Yogyakarta: Penerbit Kanisius.

Huberman, A. M. (2007). Analisis Data Kualitatif. Jakarta: UI-PRESS. 
Lestari, S. (2012). Psikologi Keluarga: Penanaman Nilai dan Penanganan Konflik dalam Keluarga. Jakarta: Prenada Media Group. Diperoleh dari website: http://www.definisi-pengertian.com/2015/04/pengertian-keluarga-definisi-menurutpara-ahli.html.

Merdeka. (2013). Peristiwa. Diperoleh dari website: https://www.merdeka.com/peristiwa/pascalebaran-jumlah-psk-di bekasi-diprediksimeningkat.html.

PortalIndonesiaNews. (2015). Pengguna Narkoba di Indonesia Capai 5 juta Orang. Diperoleh dari website: http://www.portalindonesianews.com/posts /view/1626/tahun_2015_jumlah_pengguna_narkoba_di_indonesia_capai_5_juta_ora ng.

Rafiq, M. (2014). "Hubungan Pola Komunikasi Interpersonal dalam Keluarga dan Interaksi Sosial Terhadap Kenakalan Siswa SMA Swasta di Kota Padangsidimpuan”. Tazkir Vol.9 No.1 Januari-Juni 2014.

Republika. (2008). Peran Seimbang Orangtua Tunggal. Diperoleh dari website: http://www.republika.co.id/berita/shortlink/6863.

Sarwono, J. (2006). Metode Penelitian Kuantitatif Dan Kualitatif, Yogyakarta: Graha Ilmu.

Septiana, H., Nugroho, D., \& Purwandari, M. (2008). Cara Mudah Menghadapi Ujian Sosiologi. Yogyakarta: Grasindo.

Sutarni, S. \& Sukardi. (2008). M.Pd Bahasa Indonesia II. Jakarta: PT Quadra.

Widyarini, M. M. N. (2009). Seri Psikologi Populer: Relasi Orangtua \& Anak. Jakarta: Gramedia Direct.

Yin, R. K. (2004). Studi Kasus Desain \& Metode. Jakarta: Raja Grafindo Persada. 